\title{
Development and characterization of gelatin nanoparticles loaded with a cocoa-derived polyphenolic extract
}

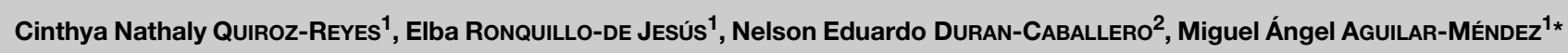

${ }^{1}$ Lab. Biomater., Cent. Investig. Cienc. Apl. Tecnol. Av. Inst. Politéc Nac., Legaria 694, Colonia Irrigación, C.P. 11500 , México D.F.

${ }^{2}$ Lab. Quím. Biol., Inst. Quím., Univ. Estadual Campinas, Cid. Univ. Zeferino Vaz, Barão Geraldo, 13083-970, Campinas, Sao Paulo, Brazil, maguilarme@ipn.mx
${ }^{*}$ Correspondence and reprints

Received 22 January 2014 Accepted 26 March 2014

Fruits, 2014, vol. 69, p.481-489 (C) 2014 Cirad/EDP Sciences All rights reserved

DOI: $10.1051 /$ fruits/2014034 www.fruits-journal.org

RESUMEN ESPAÑOL, p. 489

\section{Development and characterization of gelatin nanoparticles loaded with a cocoa-derived polyphenolic extract.}

Abstract - Introduction. Polyphenols have received significant attention in recent years due to their antioxidant capacity and their significant role in disease prevention. Cocoa is one of the major naturally occurring sources of antioxidants, particularly of polyphenolic compounds. Materials and methods. Gelatin nanoparticles loaded with a cocoa-derived polyphenolic extract were synthesized by nanoprecipitation. The nanoparticle synthesis was performed using a central composite experimental design that allowed for the assessment of how gelatin concentration and surfactant concentration (Tween 80) affected the hydrodynamic diameter and polydispersity of the particles. The nanoparticles were characterized using dynamic light scattering (DLS), assessments of zeta potential, scanning electron microscopy (SEM) and Fourier transform infrared spectroscopy (FT-IR). Results. The analyses demonstrated that the nanoparticles examined exhibited hydrodynamic diameters of (100 to 400) nm, polydispersity indices of less than 0.2 and average zeta potential values of $29-33 \mathrm{mV}$. SEM images revealed that most nanoparticles were spherical and uniform in morphology, with average sizes less than $250 \mathrm{~nm}$. In vitro experiments in which the 2,2-diphenyl-1-picrylhydrazyl (DPPH) method was used to assess the prevalence of free radical-scavenging ability among these nanoparticles indicated that the loading efficiency for the nanoparticles was approximately $77.56 \%$. Conclusion. Nanoparticles loaded with polyphenolic extract were obtained with average sizes ranging from (120 to 250$) \mathrm{nm}$ and largely spheroidal morphologies. Polymer and surfactant concentrations significantly influenced the hydrodynamic diameters and polydispersity indices of the particles. The incorporation of the polyphenolic extract into the polymer matrix enabled the preservation of the antiradical activity of the bioactive compound.

Mexico / Theobroma cacao / nanotechnology / polyphenols / antioxidants / microencapsulation / gelatin

Développement et caractérisation des nanoparticules de gélatine chargée avec un extrait polyphénolique dérivé du cacao.

Résumé - Introduction. Les polyphénols ont suscité un intérêt considérable au cours de ces dernières années en raison de leur pouvoir antioxydant et de leur rôle important dans la prévention des maladies. Le cacao est l'une des principales sources naturelles d'antioxydants, notamment de composés polyphénoliques. Matériel et méthodes. Des nanoparticules de gélatine chargées avec un extrait polyphénolique dérivé de cacao ont été synthétisées par nanoprécipitation. La synthèse de nanoparticules a été réalisée en utilisant un modèle expérimental composite central qui a permis d'évaluer comment la concentration en gélatine et la concentration en tensioactif (Tween 80) affectaient le diamètre hydrodynamique et la polydispersité des particules. Les nanoparticules ont été caractérisées en utilisant la diffusion dynamique de lumière, l'évaluation du potentiel zêta, la microscopie électronique à balayage (MEB) et la spectroscopie infrarouge à transformée de Fourier (FT-IR). Résultats. Les analyses ont montré que les nanoparticules examinées présentaient des diamètres hydrodynamiques de $(100$ à 400$) \mathrm{nm}$, des indices de polydispersité inférieurs à 0,2 et des valeurs moyennes du potentiel zêta de $(29$ à 33) $\mathrm{mV}$. Les images de la MEB ont montré que la plupart des nanoparticules étaient sphériques et de morphologie uniforme avec des tailles moyennes inférieures à $250 \mathrm{~nm}$. Des expériences in vitro, dans lesquelles la méthode du 2,2-diphényl-1-picrylhydrazyl (DPPH) a été utilisée pour évaluer la fréquence de la capacité de piégeage des radicaux libres chez ces nanoparticules, ont indiqué que l'efficacité de chargement des nanoparticules était d'environ $77,56 \%$. Conclusion. Les nanoparticules chargées d'extrait polyphénolique ont été obtenus avec des tailles moyennes allant de (120 à 250) nm et des morphologies en grande partie sphérö̈dales. Les concentrations en polymères et en agents tensio-actifs ont influencé de manière significative les diamètres hydrodynamiques et les indices de polydispersité des particules. L'incorporation de l'extrait polyphénolique dans la matrice polymère permet la préservation de l'activité anti-radicalaire du composé bioactif.

Mexique / Theobroma cacao / nanotechnologie / polyphénol / antioxydant / microencapsulation / gélatine 


\section{Introduction}

Due to their oxidation-reduction activity, polyphenols have antioxidant and cardioprotective properties that cause these compounds to be excellent hydrogen donors which not only stabilize various free radicals, such as reactive oxygen, hydroxyl and superoxide species, but also chelate iron and other transition metals [1]. Moreover, because cocoa contains high levels of phenolic compounds (primarily procyanidins and flavonols), cocoa-derived polyphenols have been recognized as a major dietary source of antioxidants [2]. It has even been observed that cocoa-based products have higher antioxidant capacity and higher flavonoid content (per serving) than tea or red wine [3]. Therefore, a diet rich in cocoaderived polyphenolic compounds may have the potential to lower the risks of chronic degenerative diseases [4-7]. However, the effectiveness of these compounds in the prevention of chronic diseases is dependent on the preservation of the stability, bioactivity and bioavailability of the active ingredients. This issue represents a major concern; in particular, orally ingested cocoa-derived polyphenolic compounds exhibit low bioavailability due to these compounds' short gastric residence times in gastric juice and low permeability and/or solubility in the small intestine. The instability of these compounds under conditions encountered during the processing and storage of food (such as unsuitable temperature, oxygen and light levels) and within the gastrointestinal tract (including deleterious effects caused by $\mathrm{pH}$ levels, enzymes or the presence of other nutrients, among other factors) also reduces the bioavailability of these molecules [8]. The use of these compounds therefore requires the design of systems to protect and preserve the active forms of these molecules until they are consumed and subsequently released within the body [9].

Gelatin is an animal protein that is widely used as a biopolymer in the production of numerous food and pharmaceutical products. This protein is obtained via acid or alkaline hydrolysis; its main properties include not only the ability to form gels and films but also good solubility in water [10, 11]. Gelatin has also been used in the manufacture of micro- and nanoparticles (nanocapsules and nanospheres) to capture, transport and release drugs that specifically target particular cells or tissues [12, 13].

Nanocapsules or nanospheres can be obtained using different preparation methods (solvent displacement and interfacial deposition, emulsification-solvent evaporation, emulsification-diffusion, double-emulsification, layer-by-layer, polymer coating, etc.) $[14,15]$. Nanocapsules are vesicular systems in which the active substance is confined to a cavity that consists of an inner (liquid, solid or gas) core surrounded by a polymer membrane. In nanocapsules, active substances are typically dissolved within the inner core, although they can also be adsorbed onto the capsule surface [9]. In contrast, nanospheres are systems that feature a polymer matrix in which the active substance is physically and uniformly scattered [16]. Relative to micro-sized particles, nanomaterials provide increased surface area; moreover, for certain bioactive compounds, the use of nanomaterials represents an excellent approach for overcoming instability, increasing solubility, masking unpleasant taste, improving bioavailability and enhancing shelf life [17, 18]. According to Acosta, the use of particles smaller than $500 \mathrm{~nm}$ can significantly improve the bioavailability of various active substances, such as $\beta$-carotene, MK-0869 (Aprepitant) and vinpocetine [19].

Nanoscale release systems are not limited to the pharmaceutical industry but have also been used in the food industry to mediate the release of flavoring compounds and nutraceuticals (such as vitamins, probiotics and antioxidants) $[20,21]$. However, no reports have addressed the design of nanoscale systems to preserve the antioxidant activity of polyphenols extracted from cocoa. Therefore, the objective of our study was to develop and characterize nanoparticles loaded with a cocoa bean-derived polyphenolic extract. 


\section{Materials and methods}

\subsection{Materials}

Cocoa beans were purchased from a local market in Mexico City. Gallic acid, 2,2diphenyl-1-picrylhydrazyl (DPPH), FolinCiocalteu reagent, Tris-HCl buffer, 2,4,6 Tris(2-pyridyl)-s-triazine (TPTZ) and ferric chloride hexahydrate were purchased from Sigma-Aldrich (USA). Acetic acid, ascorbic acid and sodium acetate were obtained from J.T. Baker (Mexico). The solvents used in our study were of analytical reagent grade.

\subsection{Extract preparation}

The ultrasound-assisted extraction of polyphenols from cocoa beans was performed following a methodology previously reported [22]. Cocoa cotyledon was ground and subsequently defatted with hexane for $24 \mathrm{~h}$ at room temperature $\left(25^{\circ} \mathrm{C}\right)$. In the first extraction, a specific quantity of cocoa powder $[(0.20 \pm 0.05) \mathrm{mm}$ particle size $]$ was added to an acidified solution (0.8\%, $2 \mathrm{~N} \mathrm{HCl}$ ) of water-methanol (50:50) and subjected to ultrasonication (at $25 \mathrm{kHz}$ ) for $30 \mathrm{~min}$. The resulting mixture was centrifuged (3,000 rpm, $15 \mathrm{~min})$ and filtered. The recovered residue was subjected to a second extraction using an acetone-water solution (70:30) and the same ultrasonication conditions. The mixture was centrifuged as described above, and the supernatants obtained from both extractions were combined. A material:solvent ratio of 1:20 was used for each extraction. Finally, the extracts were concentrated using a rotovap, dried and stored in amber bottles.

\subsection{Preparation of nanoparticles loaded with polyphenolic extract}

Nanoencapsulation was performed by nanoprecipitation following the conditions shown in the central composite design (table I). In a typical experiment, $2 \mathrm{mg}$ of polyphenolic extract were dissolved in a water-methanol solution $(70: 30,2 \mathrm{~mL})$, adding a specific quantity of gelatin. The mixture was then stirred $(300 \mathrm{rpm})$ and maintained at a constant temperature $\left(45^{\circ} \mathrm{C}\right.$ ) for $30 \mathrm{~min}$. The resulting solution was added dropwise to an ethanolic solution of Tween $80(30 \mathrm{~mL})$. After the desired solution was obtained, glutaraldehyde (5\%) was added as a crosslinking agent at a glutaraldehyde:gelatin ratio of 0.125:1. The resulting suspension was stirred (at $500 \mathrm{rpm}$ ) for $30 \mathrm{~min}$ and incubated for $12 \mathrm{~h}$ at room temperature.

\subsection{Nanoparticle size distribution and zeta potential measurements}

The Zetasizer Nano ZS ZEN3600 (Malvern Instruments, UK) was used to measure the hydrodynamic diameter and polydispersity index of nanoparticles by dynamic light scattering (DLS), and zeta potentials. Measurements for nanoparticle size and zeta potentials were performed in triplicate, with each measurement conducted using $1 \mathrm{~mL}$ of suspension at room temperature $\left(25^{\circ} \mathrm{C}\right)$. The calculations of electrophoretic mobility were automatically converted into zeta potential values, based on the Smoluchowski model; ten readings were obtained to calculate the average electrical charge.

\section{Table I.}

Experimental design used in the nanoprecipitation process for studying the characterization of gelatin nanoparticles loaded with a cocoa-derived polyphenolic extract.

$\begin{array}{ccc}\text { Assay } & \begin{array}{c}\text { Gelatin } \\ (\% \mathrm{w} / \mathrm{v})\end{array} & \begin{array}{c}\text { Surfactant } \\ (\% \mathrm{w} / \mathrm{v})\end{array} \\ \text { NP-01 } & 1.00 & 1.00 \\ \text { NP-02 } & 3.00 & 1.00 \\ \text { NP-03 } & 1.00 & 3.00 \\ \text { NP-04 } & 3.00 & 3.00 \\ \text { NP-05 } & 0.80 & 2.00 \\ \text { NP-06 } & 3.41 & 2.00 \\ \text { NP-07 } & 2.00 & 0.80 \\ \text { NP-08 } & 2.00 & 3.41 \\ \text { NP-09 } & 2.00 & 2.00 \\ \text { NP-10 } & 2.00 & 2.00 \\ \text { NP-11 } & 2.00 & 2.00 \\ \text { NP-12 } & 2.00 & 2.00 \\ \text { NP-13 } & 2.00 & 2.00\end{array}$




\subsection{Fourier Transform Infrared (FT-IR) spectra}

The presence of polyphenol extract in the loaded nanoparticles and the interaction with the surfactant was studied by Fourier Transform Infrared (FT-IR) spectroscopy. An Agilent Cary 630 FTIR spectrometer (Agilent Tecnologies, USA) was used to record IR spectra. A certain amount of surfactant, gelatin, dry extract and loaded nanoparticles were placed in the sampler window of the diamond ATR (attenuated total reflection) accessory; spectra were obtained when the press was closed and the sample had contact with the ATR crystal.

\subsection{Scanning electron microscopy (SEM)}

Nanoparticle size and morphology were determined by observing nanoparticles under a scanning electron microscope (JEM6390LV, JEOL, Japan). The samples examined were coated with silver; subsequently, images were obtained at various magnifications, using an accelerating voltage of $20 \mathrm{kV}$.

\subsection{Loading efficiency assessment by radical scavenging activity (DPPH)}

In accordance with the method described by Lee et al. [11], suspended nanoparticles were washed with ethanol and centrifuged at $9,000 \mathrm{rpm}$. The precipitate was redispersed in ethanol, and $4 \mathrm{~mL}$ of the resulting dispersion was added to $40 \mathrm{~mL}$ of phosphate buffer ( $\mathrm{pH} 7)$. A total of $4 \mathrm{~mL}$ of acetylated trypsin had previously been added to the release medium (the buffer) to degrade the gelatin. The mixture was constantly stirred at room temperature for $12 \mathrm{~h}$. At the conclusion of the enzymatic degradation, ten $\mathrm{mL}$ of solution was filtered through Whatman No. 42 filter paper. The DPPH assay was carried out according to the method of Lim et al. [23], with some modifications. A 2-mL aliquot of the filtered solution was mixed with $500 \mu \mathrm{L}$ of $0.1 \mathrm{M}$ Tris-HCl buffer and $2 \mathrm{~mL}$ of $200 \mu \mathrm{M}$ DPPH solution. The resulting mixture was stirred and incubated in the dark for $30 \mathrm{~min}$ at room temperature. Finally, absorbance at $517 \mathrm{~nm}$ was recorded and used to determine the extent to which free radicals were inhibited (Eq. 1).

DPPH inbibtion $\%=$
$\left(1-\frac{\text { absorbance of sample }}{\text { absorbance of control }}\right) \times 100$

Through the use of a calibration curve and equation 2, the known quantity of polyphenolic extract treated by nanoencapsulation and the quantity of extract that retains free radical scavenging capacity in the nanoparticles examined, which was determined as described above, could be utilized to quantify loading efficiency [24].

Polyphenolic extract loading efficency $\%=$

$\left(\frac{\text { actual polyphenolic extract loading }(\mathrm{mg})}{\text { theorical polyphenolic extract loading }(\mathrm{mg})}\right) \times 100(2)$

\subsection{Statistical analysis}

Response surface methodology was used (Design-Expert 8, Stat-Ease Inc., USA) to determine the effects of polymer (gelatin) and surfactant (Tween 80) concentrations on the hydrodynamic diameter and polydispersity of particles. Analyses of variance and $F$-tests were employed to determine the significance of differences between treatment means (using a significance threshold of $P<0.05)$.

\section{Results and discussion}

\subsection{Hydrodynamic diameter and polydispersity index}

Our results regarding the effects of gelatin and surfactant concentrations on the hydrodynamic diameters and polydispersity indices, respectively, of the nanoparticles examined show that, regardless of surfactant concentration, both the hydrodynamic diameter and the polydispersity index increase as gelatin concentration increases (figures 1, 2). One explanation for this phenomenon is that increases in polymer concentration are accompanied by increases in the viscosity of the system 
examined, which causes diffusion from the solvent phase to become increasingly difficult and results in the agglomeration of particles [25]. However, increments in Tween 80 concentration were associated with decreases in hydrodynamic diameters and polydispersity indices, particularly at gelatin concentrations greater than $1.5 \%$. Nonionic surfactant concentrations may influence the mechanism by which molecules enter the ethanolic phase, a process that enables nanoparticle stabilization and deposition [26]. This entry of molecules into the ethanolic phase decreases surface tension and viscosity, preventing agglomeration and promoting uniform particle distribution. Thus, higher concentrations of surfactant result in lower hydrodynamic diameters and polydispersity indices [27]. The factors evaluated in the design examined exhibited a statistically significant relationship $(P<0.05)$ with the response variables; however, no synergistic effects linking the influences of these factors were observed. Equation 3 specifies a mathematical model for hydrodynamic diameter (HD) with a correlation coefficient $\left(R^{2}\right)$ of 0.96 , indicating that this model fits the experimental data well.

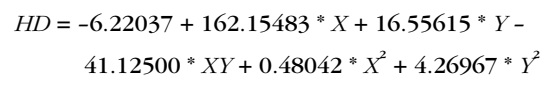

where HD is the hydrodynamic diameter; $X$ and $Y$ denote the gelatin and surfactant concentration $(\% \mathrm{~m} / \mathrm{v})$, respectively. Moreover, equation 4 specifies a mathematical model for the polydispersity index (IP) with $P<$ 0.05 and $R^{2}=0.82$; once again, this high correlation coefficient indicates that the model fits the experimental data well.

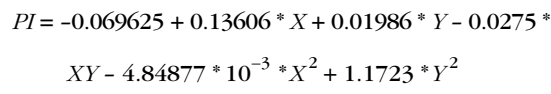

\subsection{Zeta potentials of nanoparticles loaded with polyphenolic extract}

The zeta potentials of nanoparticle suspensions were determined at $\mathrm{pH} 5.2$ using the NP-09, NP-07 and NP-04 assays; these assays were chosen because they exhibited greater particle stability both at room

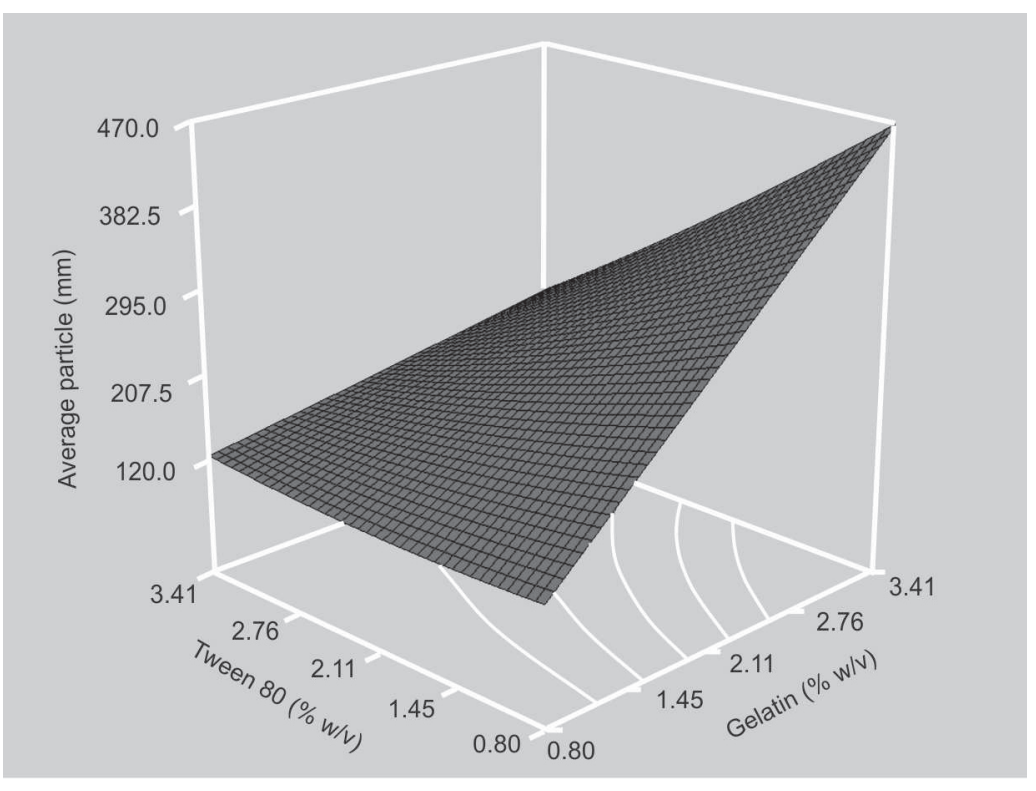

Figure 1.

Influence of the concentration of gelatin and surfactant on the hydrodynamic diameter of the nanoparticles loaded with polyphenolic extract.

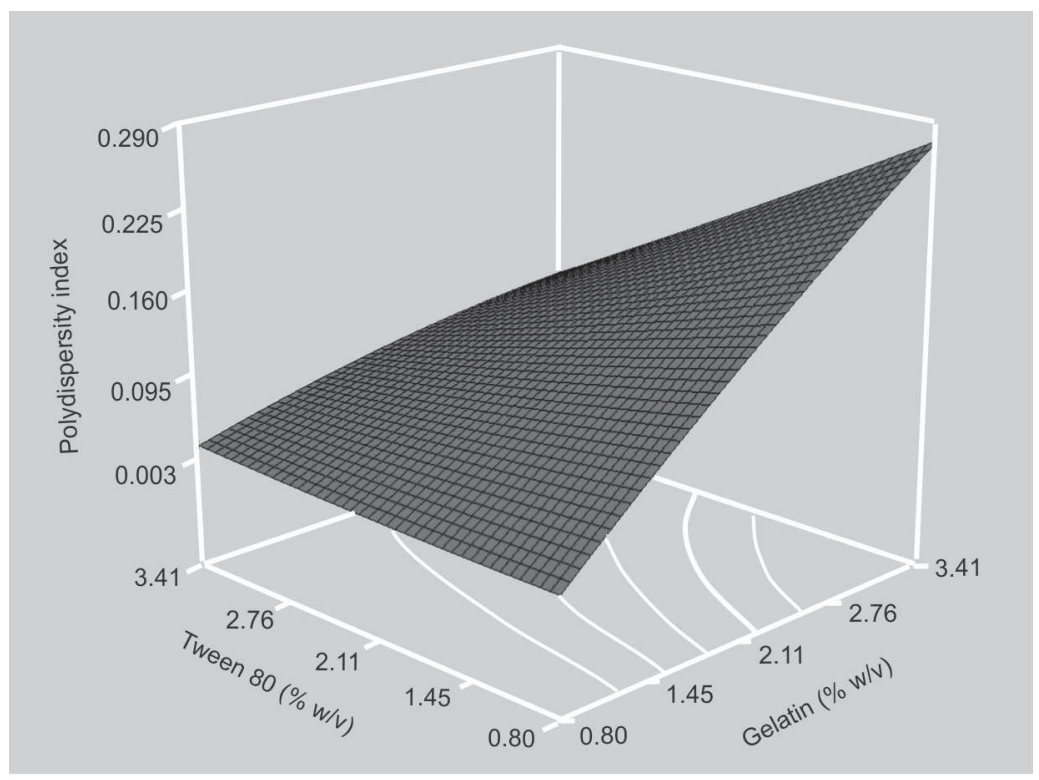

Figure 2.

Influence of the concentration of gelatin and surfactant on the polydispersity index of the nanoparticles loaded with polyphenolic extract.

temperature and in fridge conditions than other experiments where particles precipitated, forming aggregates two days after synthesis. The measured zeta potential 


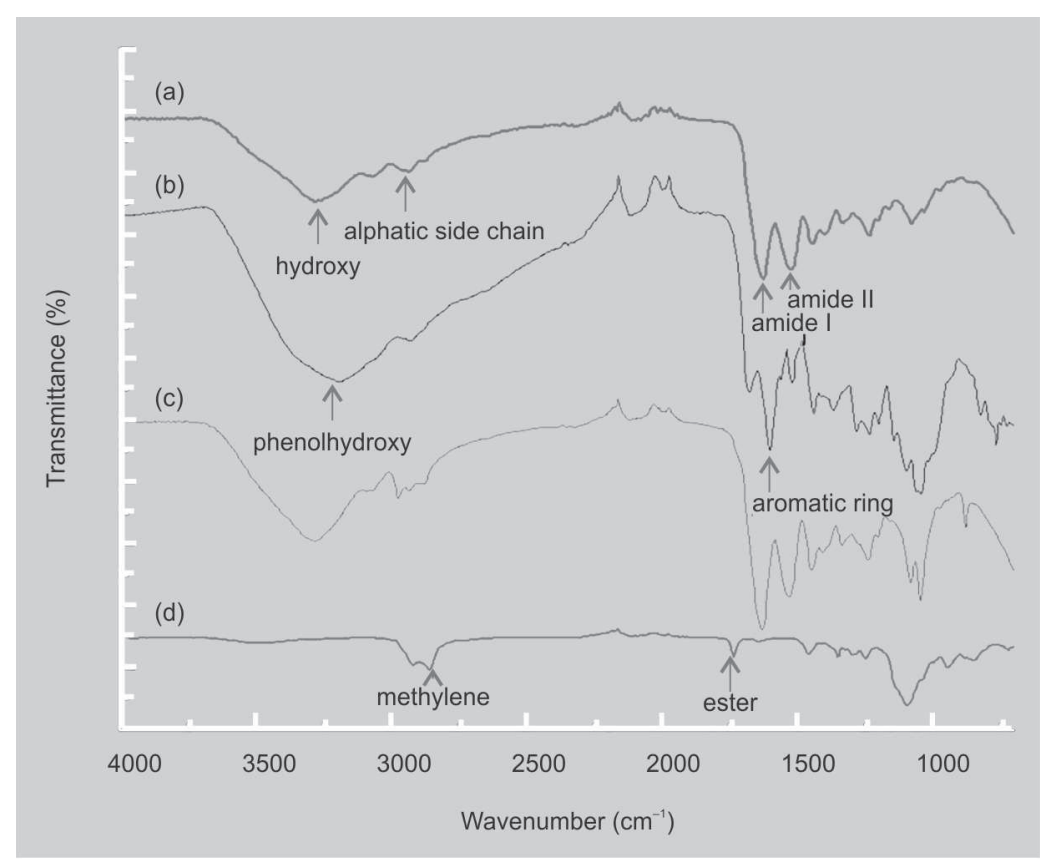

Figure 3.

Fourier Transform Infrared (FT-IR) spectra of gelatin (a), phenolic extract $(b)$, gelatin nanoparticles loaded with phenolic extract (c) and surfactant Tween 80 (d). values ranged from $29-33 \mathrm{mV}$, indicating the predominance of positive charges and illustrating the stability of these suspensions. According to Mora et al., the charge of the zeta potential of nanoparticles in suspension is mainly dependent on the chemical characteristics of the polymer, the type of stabilizer and the $\mathrm{pH}$ of the medium used in the suspension [15]. The cationic behavior of the suspensions examined in this study can be attributed to lysine and arginine residues present in the molecular structure of gelatin; these residues protonate at a $\mathrm{pH}$ below their isoelectric point (pH 6.1), influencing overall zeta potential charge [28]. Statistical analyses (using Tukey's test) revealed significant differences in the results of the NP-07 [(29.56 \pm $0.65) \mathrm{mV}]$ and NP-09 [(33.23 \pm 2.00$) \mathrm{mV}]$ assays. However, the zeta potential values obtained in the NP-04 assay [(30.26 \pm 1.18) $\mathrm{mV}$ ] did not significantly differ from the zeta potential values obtained in the NP-07 and NP-09 assays. The significant difference between NP-07 and NP-09 assays could be explained because NP-07 had a lower percentage of surfactant $(0.80)$ than NP-09 (2.00). In this case, the results obtained in our study showed that a higher concentration of the surfactant promotes a better particle distribution. Calvo et al. reported good colloidal stability of chitosan (CS)-coated and poly-L-lysine (PLL)-coated poly-e-caprolactone nanocapsules due to the high-energy barrier between particles in correlating an increase in the absolute value of the zeta potential (25-30 mV) [29]. The resulting zeta potential probably depends on the combination of materials and possibly on certain process conditions, such as those which determine molecular organization when the polymer is reprecipitated [16].

\subsection{Interactions among the gelatin protein matrix, polyphenolic extract and surfactant}

As indicated by the FT-IR spectra of our study (figure 3), gelatin produced characteristic absorption bands at approximately $3276 \mathrm{~cm}^{-1}, \quad 2869 \mathrm{~cm}^{-1}, \quad 1627 \mathrm{~cm}^{-1}$ and $1526 \mathrm{~cm}^{-1}$, which corresponded to vibrations of the $\mathrm{O}-\mathrm{H}$ group, C-C (aliphatic chains), $\mathrm{C}=\mathrm{O}$ (amide I) and $\mathrm{N}-\mathrm{H}$ (amide II) bonds, respectively $[30,31]$. The polyphenolic extract produced characteristic absorption bands at $3200 \mathrm{~cm}^{-1}$ and $1594 \mathrm{~cm}^{-1}$, which corresponded to vibrations of the $\mathrm{O}-\mathrm{H}$ bond in phenolic hydroxyl groups and the $\mathrm{C}=\mathrm{C}$ bonds in aromatic rings, respectively [32]. Tween 80 produced bands at $2923 \mathrm{~cm}^{-1}$ and $2859 \mathrm{~cm}^{-1}$, which corresponded to asymmetric and symmetric vibrations of methylene $\left(\mathrm{CH}_{2}\right)$, respectively; moreover, the Tween 80 FT-IR spectrum also exhibited a $1725 \mathrm{~cm}^{-1}$ band, which was produced by stretching vibrations of ester group $\mathrm{C}=\mathrm{O}$ bonds [33, 34]. In the FT-IR spectra of nanoparticles, a change in the characteristic absorption band of gelatin at $2869 \mathrm{~cm}^{-1}$ was observed; this alteration can be attributed to hydrophobic interactions between methylene groups of surfactant molecules and the aliphatic chains of gelatin molecules [30]. In addition, the intensification of the peak at approximately $1627 \mathrm{~cm}^{-1}$ in the nanoparticle spectra relative to the gelatin spectra can be explained by the hydrogen-bonding interactions between the $\mathrm{C}=\mathrm{O}$ group of gelatin and $\mathrm{O}-\mathrm{H}$ groups 


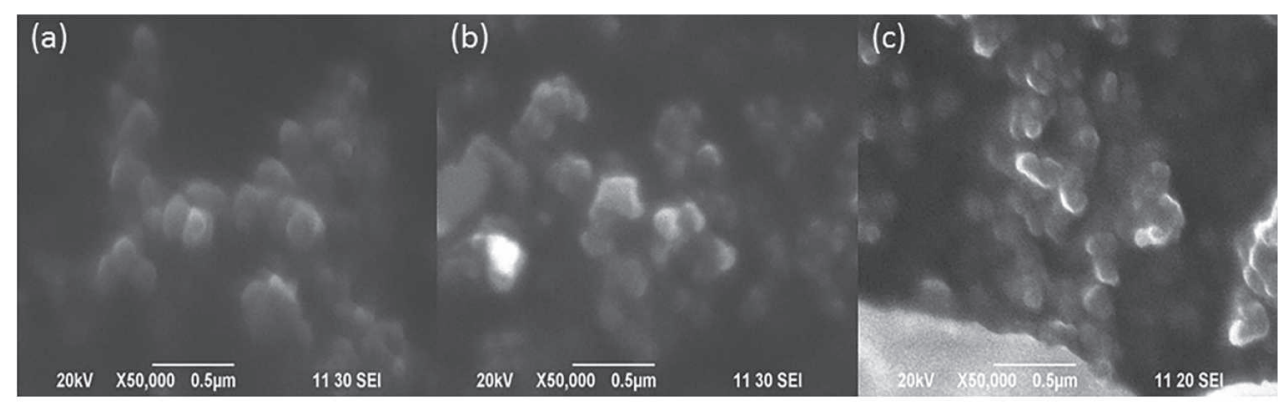

of the polyphenolic extract that occurred in the nanoparticles [31].

\subsection{Size and morphology of nanoparticles}

Selected samples were analyzed by SEM (figure 4). The SEM micrographs indicated that nanoparticles generally exhibited spheroidal morphologies and a uniform size distribution, with mean particle sizes of 130-200 nm for the NP-04 and NP-09 samples and 120-250 nm for the NP-07 sample. Presumably, the glutaraldehyde used in the experiments of our study significantly affected the morphology, size and size distribution characteristics of the samples analyzed, as reports have indicated that glutaraldehyde promotes crosslinking and the formation of particles with regular shape and morphology during nanoprecipitation [11, 35].

\subsection{In vitro evaluations of the antiradical activity (using DPPH) of nanoparticles loaded with polyphenolic extract}

In a previous study we identified and quantified the flavonoids (+)-catechin and (-)-epicatechin, and determined the antiradical activity of the extract used to formulate the nanoparticles [22]. The loading efficiency values for nanoprecipitation in the NP-09 assay were quantified by the interpolation of values from the calibration curve for this approach (Eq. 5).

$x=0.001+(y-4.61)\left(4.44 \times 10^{-3}\right)$

The theoretical quantity of dry extract loaded during this assay was
$0.0061 \mathrm{mg} \cdot \mathrm{mL}^{-1}$, and the actual loaded nanoparticles produced free radical inhibition of $5.44 \%$, which corresponded to a concentration of $0.0047 \mathrm{mg} \cdot \mathrm{mL}^{-1}$. Through the use of prior data in equation 2 , a loading efficiency of $77.56 \%$ was calculated for this assay.

According to the literature, the loading efficiency of gelatin nanoparticles may vary depending on the method used for nanoparticle synthesis and the compound that is encapsulated. For instance, efficiencies of 10.6-59.3\% have been reported for loading the drugs tizanidine and gatifloxacin into gelatin nanoparticles prepared by nanoprecipitation [11]. Chen et al. reported a loading efficiency of $96.6 \%$ for the self-assembly of catechin nanoparticles in a process based on the theoretical principle of polymer solution precipitation in a partially miscible solvent [31].

The tendency of polyphenols to be absorbed into or adsorbed onto a protein matrix is largely dependent on interactions between the functional groups of the compounds in question [36, 37]. Most polyphenols, including gallic acid, tannic acid and catechins, are known for their ability to precipitate proteins (such as albumin, casein and gelatin) in aqueous solution, although the strength of the protein-polyphenol bond can vary greatly depending on the particular protein and polyphenol molecules involved [17]. In this nanoencapsulation process, such a bond or interaction could promote loading efficiency [31].

\section{Acknowledgments}

This work was financially supported by SIP-IPN (projects: 20113551 and 20120422).
Figure 4.

Scanning electron microscopy (SEM): images of gelatin nanoparticles loaded with polyphenolic extract; (a) NP-04 assay, (b) NP-07 assay and (c) NP-09 assay. 
Quiroz-Reyes thanks COFAA-IPN and CONACyT for the scholarships received.

\section{References}

[1] Lee J., Koo N., Min D.B., Reactive oxygen species, ageing, and antioxidative nutraceuticals, Compr. Rev. Food Sci. Food Saf. 3 (2004) 21-33.

[2] Belšcak A., Komes D., Horzic D., KovacevicGanic K. , Karlovi D., Comparative study of commercially available cocoa products in terms of their bioactive composition, Food Res. Int. 42 (2009) 707-716.

[3] Jonfia-Essien W.A., West G., Alderson P.G., Tucker G., Phenolic content and antioxidant capacity of hybrid variety cocoa beans, Food Chem. 108 (2008) 1155-1159.

[4] Hirano R., Osakabe N., Iwamoto A., Matsumoto A., Natsume M., Antioxidant effects of polyphenols in chocolate on lowdensity lipoprotein both in vitro and ex vivo, J. Nutr. Sci. Vitaminol. 46 (2000) 199-204.

[5] Hirano R., Sasamoto W., Matsumoto A., Itakura H., Igarashi O., Kondo K., Antioxidant ability of various flavonoids against DPPH radicals and LDL oxidation, J. Nutr. Sci. Vitaminol. 47 (2001) 357-362.

[6] Osakabe N., Baba S., Yasuda A., Daily cocoa intake reduces the susceptibility of low-density lipoprotein to oxidation as demonstrated in healthy humans volunteers, Free Radic. Res. 34 (2001) 93-99.

[7] Weisburger J., Chemopreventive effects of cocoa polyphenols of chronic diseases, Exp. Biol. Med. 226 (2001) 891-897.

[8] Osakabe N., Cacao polyphenols and atherosclerosis, J. Clin. Biochem. Nutr. 37 (2005) 67-72.

[9] Fang Z., Bhandari B., Encapsulation of polyphenols - a review, Trends Food Sci. Technol. 21 (2010) 510-523.

[10] Zwiorek K., Gelatin nanoparticles as delivery system for nucleotide-based drugs, LudwigMaximilians-Univ., Thesis, Munich, Germany, 2006, $215 \mathrm{p}$.

[11] Lee J., Khan S., Park K., Lim K., Studies on the characteristics of drug-loaded gelatin nanoparticles prepared by nanoprecipitation, Bioprocess. Biosyst. Eng. 35 (2011) 297-307.
[12] Junyaprasert V.B., Mitrevej A., Sinchaipanid N., Boonme P., Wurster D.E., Effect of process variables on the microencapsulation of vitamin A palmitate by gelatin-acacia coacervation, Drug Dev. Ind. Pharm. 27 (2001) 561-566.

[13] Hamidi M., Azadi A., Rafiei P., Hydrogel nanoparticles in drug delivery, Adv. Drug Deliv. Rev. 60 (2008) 1638-1649.

[14] Mohanraj V.J., Chen Y., Nanoparticles - a review, Trop. J. Pharm. Res. 5 (2006) 561573.

[15] Mora C.E., Fessi H., Elaissari A., Polymerbased nanocapsules for drug delivery, Int. J. Pharm. 385 (2010) 113-142.

[16] Konan Y.N., Gurny R., Allémann E., Preparation and characterization of sterile and freeze-dried sub-200 nm nanoparticles, Int. J. Pharm. 233 (2002) 239-252.

[17] Shutava T., Balkundi S., Vangala P., Steffan J., Bigelow R., Cardelli J., O’Neal P., Lvov Y., Layer-by-layer-coated gelatin nanoparticles as a vehicle for delivery of natural polyphenols, Am. Chem. Soc. 3 (2009) 1877-1885.

[18] Mozafari M.R., Mortazavi S.M., Nanoliposomes: From fundamentals to recent developments, in: Weissing V. (Ed.), Liposomes, vol. 1, Pharmaceutical nanocarriers, $R$. Humanis Press, N.Y., U.S.A., 2010.

[19] Acosta E., Bioavailability of nanoparticles in nutrient and nutraceutical delivery, Curr. Opin. Colloid Interface Sci. 14 (2009) 3-15.

[20] Linforth R.S.T., Pearson K.S.K., Taylor A.J., In vivo flavor release from gelatin-sucrose gels containing droplets of flavor compounds, J. Agric. Food Chem. 55 (2007) 7859-7863.

[21] Chen L., Remondetto G.E., Subirade M., Food protein-based materials as nutraceutical delivery systems, Trends Food Sci. Technol. 17 (2006) 272-283.

[22] Quiroz-Reyes C.N., Aguilar-Méndez M.A., Ramírez-Ortiz M.E., Ronquillo-de Jesús E., Comparative study of ultrasound and maceration techniques for the extraction of polyphenols from cocoa beans (Theobroma cacao L.), Rev. Mex. Ing. Quím. 12 (2013) 12-18.

[23] Sze Lim Y., Sze Hui Lee S., Chin Tan B., Antioxidant capacity and antibacterial activity of different parts of mangosteen (Garcinia mangostana Linn.) extracts, Fruits 68 (6) (2013) 483-489. 
[24] Naidu K., Paulson A., A new method for the preparation of gelatin nanoparticles: Encapsulation and drug release characteristics, $\mathrm{J}$. Appl. Polym. Sci. 121 (2010) 3495-3500.

[25] Bilati U., Allemann E., Doelker E., Development of a nanoprecipitation method intended for the entrapment of hydrophilic drugs into nanoparticles, Eur. J. Pharm. Sci. 24 (2005) 67-75.

[26] Quintanar D., Allémann E., Fessi H., Doelker E., Preparation techniques and mechanisms of formation of biodegradable nanoparticles from preformed polymers, Drug Dev. Ind. Pharm. 24 (1998) 1113-1128.

[27] Rodriguez J.M., Rodriguez M.R., Sanchez C.C., Physico-chemical properties of surfactant and protein films, Curr. Opin. Colloid Interface Sci. 12 (2007) 187-195.

[28] Samal K.S., Dash M., Van Vlierberghe S., Kaplan L., Chiellini E., van Blitterswijk C., Moroni L., Cationic polymers and their therapeutic potential, Chem. Soc. Rev. 41 (2012) 7147-7194.

[29] Calvo P., Vila-Jato J.L., Alonso M.J., Evaluation of cationic polymer-coated nanocapsules as ocular drug carriers, Int. J. Pharm. 153 (1997) 41-50.

[30] Pinotti A., Garcia M., Martino M., Zaritzky N., Study on microstructure and physical properties of composite films based on chitosan and gelatin, Food Hydrocoll. 21(2007) 66-72.
[31] Chen Y.C., Yu S.H, Tsai G.J., Tang D.W., Mi F.L., Peng Y.P., Novel technology for the preparation of self-assembled catechin/gelatin nanoparticles and their characterization, J. Agric. Food Chem. 58 (2010) 6728-6734.

[32] Zhu B., Li J., He Y., Yoshie N., Inoue Y., Hydrogen-bonding interaction and crystalline morphology in the binary blends of poly( $\varepsilon$-caprolactone) and polyphenol catechin, Macromol. Biosci. 3 (2003) 684-693.

[33] Ren W., Tian G., Jian S., Gu Z., Zhou L., Yan L., Jin S., Yin W., Zhao Y., Tween coated NaYF4:Yb,Er/NaYF4 core/shell upconversion nanoparticles for bioimaging and drug delivery, RSC. Adv. 2 (2012) 7037-7041.

[34] Souza J., Feitosa J., Ricardo N., Trevisan M., de Paula H., Ulrich C., Owen R., Spraydrying encapsulation of mangiferin using natural polymers, Food Hydrocoll. 33 (2013) 10-18.

[35] Leo E., Cameroni R., Forni F., Dynamic dialysis for the drug release evaluation from doxorubicin-gelatin nanoparticles conjugates, Int. J. Pharmacol. 180 (1999) 23-30.

[36] Bennick A., Interaction of plant polyphenols with salivary proteins, Crit. Rev. Oral Biol. Med. 13 (2002) 184-196.

[37] Yi K., Cheng G., Xing F. Gelatin/tannin complex nanospheres via molecular assembly, J. Appl. Polym. Sci. 101 (2006) 3125-3130.

\section{Desarrollo y caracterización de nanopartículas de gelatina cargadas con un extracto polifenólico derivado del cacao.}

Resumen - Introducción. Los polifenoles han ganado un interés significativo en años recientes debido a su capacidad antioxidante y a su rol significativo en la prevención de enfermedades. El cacao es una de las principales fuentes naturales de antioxidantes, particularmente de compuestos polifenólicos. Materiales y métodos. Nanopartículas de gelatina cargadas con un extracto polifenólico derivado del cacao fueron sintetizadas por nanoprecipitación. La síntesis de nanopartículas fue realizada empleando un diseño experimental central compuesto, el cual permitió estudiar el efecto de la concentración de gelatina y la concentración de surfactante (Tween 80) en el diámetro hidrodinámico y polidispersidad de las partículas. Las nanopartículas fueron caracterizadas usando dispersión de luz dinámica, potencial zeta, microscopia electrónica de barrido (MEB) y espectroscopia de infrarrojo con transformada de Fourier (FT-IR). Resultados. Los análisis demostraron que las partículas examinadas exhibieron diámetros hidrodinámicos de (100 a 400) $\mathrm{nm}$, índices de polidispersidad menores a 0,2 y valores promedio de potencial zeta de $29-33 \mathrm{mV}$. Las imágenes de MEB revelaron que la mayoría de las nanopartículas fueron esféricas y de morfología uniforme con tamaños promedio menores a $250 \mathrm{~nm}$. Los experimentos in vitro en los cuales el método del 2,2-difenil1-picrilhidrazil (DPPH) fue usado para estudiar la prevalencia de la habilidad secuestradora de radicales libres entre las nanopartículas indicó que la eficiencia de carga en las nanopartículas fue de aproximadamente $77,56 \%$. Conclusión. Nanopartículas cargadas con extracto polifenólico fueron obtenidas con tamaños promedio de (120 a 250) nm y morfologías principalmente esferoidales. Las concentraciones del polímero y surfactante influenciaron significativamente los diámetros hidrodinámicos y los índices de polidispersidad de las partículas. La incorporación del extracto polifenólico en la matriz polimérica permitió la preservación de la actividad antiradical del compuesto bioactivo.

México / Theobroma cacao / nanotecnología / polifenoles / antioxidantes / microencapsulación / gelatina 